\title{
Infliximab Modulates Cisplatin-Induced Hepatotoxicity in Rats
}

\author{
Medine Cumhur Cüre ${ }^{1}$, Erkan Cüre ${ }^{2}$, Yıldıray Kalkan³, Aynur Kırbaş ${ }^{1}$, Levent Tümkaya ${ }^{3}$, Arif Y1lmaz ${ }^{4}$, \\ Ayşegül Küçükali Türkyılmaz ${ }^{5}$ İbrahim Şehitoğlu ${ }^{6}$, Süleyman Yüce ${ }^{7}$ \\ ${ }^{1}$ Department of Biochemistry, Recep Tayyip Erdoğan University School of Medicine, Rize, Turkey \\ ${ }^{2}$ Department of Internal Medicine, Recep Tayyip Erdoğan University School of Medicine, Rize, Turkey \\ ${ }^{3}$ Department of Histology and Embryology, Recep Tayyip Erdoğan University School of Medicine, Rize, Turkey \\ ${ }^{4}$ Department of Gastroenterology, Recep Tayyip Erdoğan University School of Medicine, Rize, Turkey \\ ${ }^{5}$ Department of Physical Medicine and Rehabilitation, Recep Tayyip Erdoğan University School of Medicine, Rize, Turkey \\ ${ }^{6}$ Department of Pathology, Recep Tayyip Erdoğan University School of Medicine, Rize, Turkey \\ ${ }^{7}$ Department of Internal Medicine, Kumru State Hospital, Rize, Turkey
}

Background: Cisplatin (Cis) is one of the most commonly used antineoplastic drugs. It is used as chemotherapy for many solid organ malignancies such as brain, neck, male and female urogenital, vesical and pulmonary cancers. Infliximab blocks tumor necrosis factor alpha $(\mathrm{TNF}-\alpha)$. Several studies have reported that infliximab ameliorates cell damage by reducing cytokine levels.

Aims: We aimed to investigate whether infliximab has a preventive effect against cisplatin-induced hepatotoxicity and whether it has a synergistic effect when combined with Cis.

Study Design: Animal experimentation.

Methods: Male Wistar albino rats were divided in three groups as follows: Cis group, infliximab $+\mathrm{Cis}$ (CIN) group and the control group. Each group comprised 10 animals. Animals in the Cis group received an intraperitoneal single-dose injection of Cis $(7 \mathrm{mg} /$ $\mathrm{kg}$ ). In the CIN group, a single dose of infliximab (7 $\mathrm{mg} / \mathrm{kg}$ ) was administered $72 \mathrm{~h}$ prior to the Cis injection. After $72 \mathrm{~h}$, a single dose of Cis $(7 \mathrm{mg} / \mathrm{kg})$ was administered. All rats were sacrificed five days after Cis injection.
Results: TNF- $\alpha$ levels in the Cis group were significantly higher $(345.5 \pm 40.0 \mathrm{pg} / \mathrm{mg}$ protein) than those of the control $(278.7 \pm 62.1 \mathrm{pg} / \mathrm{mg}$ protein, $\mathrm{p}=0.003)$ and CIN groups $(239.0 \pm 64.2 \mathrm{pg} / \mathrm{mg}$ protein, $\mathrm{p}=0.013)$. The Cis group was found to have high carbonic anhydrase (CA)-II and low carbamoyl phosphate synthetase-1 (CPS-1) levels. Aspartate transaminase (AST) and alanine transaminase (ALT) levels were lower in the CIN group as compared to the Cis group. Total histological damage was greater in the Cis group as compared to the control and CIN groups.

Conclusion: Cis may lead to liver damage by increasing cytokine levels. It may increase oxidative stressinduced tissue damage by increasing carbonic anhydrase II (CA-II) enzyme levels and decreasing CPS-1 enzyme levels. Infliximab decreases Cis-induced hepatic damage by blocking TNF- $\alpha$ and it may also protect against liver damage by regulating CPS-1 and CA-II enzyme levels.

Keywords: Carbamoyl-phosphate synthetase 1, carbonic anhydrase, cisplatin, hepatotoxicity, infliximab, tumor necrosis factor alpha 
Cisplatin (Cis) is one of the most commonly used antineoplastic drugs. It is a chemotherapeutic used for solid organ malignancies such as brain, neck, male and female urogenital system, vesical, and pulmonary cancers. The therapeutic efficacy of Cis is largely limited due to its toxic side effects, which include nephrotoxicity and hepatotoxicity. While the exact mechanism of Cis-induced hepatotoxicity is not completely understood, it is considered to be associated with oxidative damage (1). During Cis toxicity, oxidative stress and the production of reactive oxygen species (ROS) lead to an increase in the release of pro-inflammatory cytokines, such as tumor necrosis factor alpha (TNF- $\alpha$ ) and interleukin-6 (IL-6) $(2,3)$. These cytokines accelerate the apoptotic process and cellular damage. ROS are potent oxidizing and reducing agents that lead to cell membrane damage by activating neutrophils and by lipid peroxidation.

Infliximab (Ib) is an inhibitor of TNF- $\alpha$ and it was developed as a therapeutic agent for the TNF- $\alpha$-mediated disease. It binds and neutralizes TNF- $\alpha$. A previous study reported that $\mathrm{Ib}$ administration strongly diminished serum levels of alanine aminotransferase (ALT), aspartate aminotransferase (AST) and TNF- $\alpha$ in subjects with liver toxicity (4). Several studies have shown that $\mathrm{Ib}$ alleviates cellular damage by reducing ROS and cytokine levels (5-7). Ib ameliorates carbon tetrachloride-induced liver injury by decreasing the production of transforming growth factor beta and interleukin 1 beta (IL-1 $\beta$ ) and by regulating purine metabolism (8). Ib also decreases liver injury by decreasing the production of IL- $1 \beta$ and TNF- $\alpha$ that typically results from methotrexate-induced hepatotoxicity, and by decreasing the formation of peroxynitrite radicals by preventing the formation of excess nitric oxide (7).

Carbonic anhydrases (CA), such as CA-II, are zinc metalloenzymes that reversibly convert carbon dioxide to bicarbonate. They are expressed in many tissues, including the liver (9). High CA-II levels have been found to be related to carbonate radicals and some carcinomas (10). A previous study has shown that Cis overdose affects CA-II in renal tissues, leading to an acceleration of nephrotoxicity (11). However, the effect of Cis overdose on CA-II in liver tissues has not yet been reported. Carbamoyl-phosphate synthetase-1 (CPS-1) is a urea-cycle enzyme found in hepatic mitochondria. A decrease in its enzymatic activity leads to high bicarbonate levels (12). As cancer cells utilize bicarbonate as an energy source, high bicarbonate accelerates cancer cell proliferation (13).

There are no adequate studies in the literature regarding the combined use of Cis and $\mathrm{Ib}(\mathrm{CIN})$. The aim of this study was to investigate whether $\mathrm{Ib}$ prevents Cis-induced hepatotoxicity and whether usage of CIN together shows a synergistic or adverse effect.

\section{MATERIALS AND METHODS}

\begin{abstract}
Animals
Thirty Wistar albino male rats with weights of 250 to $300 \mathrm{~g}$ (12-15-week-old) were used in our study. The rats were randomly subdivided into three groups as follows: The Cis group $(n=10)$, the CIN group $(n=10)$ and the control group $(n=10)$. This research was carried out according to the Guide for the Care and Use of Laboratory Animals (NIH, 1985). This study was approved by the local ethical committee (Approval number: 2012/17).
\end{abstract}

\section{Experimental design}

An isotonic saline solution that was equal in volume to what was received by the Cis group was administered to the control group by intraperitoneal injection. The animals in the Cis group received a single-dose injection of Cis (Cisplatinum Ebewe, $0.5 \mathrm{mg} / \mathrm{mL})(7 \mathrm{mg} / \mathrm{kg})$, administered intraperitoneally, and were sacrificed five days later (14). A single dose of Ib (Remicade ${ }^{\circledR}$; Schering plough, USA) $(7 \mathrm{mg} / \mathrm{kg}$ ) was given to the CIN group rats $72 \mathrm{~h}$ prior to Cis injection (5). A single dose of cisplatin (Koçak Pharma; İstanbul, Turkey) (7 mg/kg) was given after $72 \mathrm{~h}$ and the animals were killed five days after this injection. All groups were killed under anesthesia using ketamine (Pfizer Inc, NY, USA) hydrochloride. Hepatic tissues were removed from the animals and were directly stored at $-80^{\circ} \mathrm{C}$ until analysis.

\section{Biochemical parameters}

Blood samples of $10 \mathrm{ml}$ were drawn from all rats and collected into tubes for biochemical analysis. The samples were kept at room temperature for $15 \mathrm{~min}$ before being centrifuged at 3,000 rpm for $10 \mathrm{~min}$. The biochemical parameters, such as AST and ALT, were analyzed using commercial kits (ARCHITECT c16000, Abbott Laboratories; IL, USA).

\section{Tissue homogenates}

The tissues were homogenized in phosphate-buffered saline (PBS) at $\mathrm{pH} 7.4$ and centrifuged at 10,000 g for $20 \mathrm{~min}$. Aliquots of the supernatant were frozen at $-80^{\circ} \mathrm{C}$. Levels of TNF- $\alpha$ and IL- 6 were checked within one month.

\section{Protein quantification}

A turbidimetric procedure was used to measure protein levels in the tissue homogenates, with benzethonium chloride used as a protein-denaturing agent. Proteins in the form of fine suspensions were measured using the turbidimetric method at $404 \mathrm{~nm}$ (ARCHITECT c16000, Abbott Laboratories; IL, USA) 


\section{Tissue TNF- $\alpha$}

TNF- $\alpha$ concentration was evaluated using a commercially existent rat TNF- $\alpha$ enzyme-linked immunosorbent assay (ELISA) kit (eBioscience; Vienna, Austria). The absorbance was evaluated by the ELISA plate reader at a wavelength of $450 \mathrm{~nm}$. The intra-assay coefficients of variation were $<5 \%$, and the inter-assay coefficients of variation were $<10 \%$. The limit of detection (LOD) for the TNF- $\alpha$ assay was $11 \mathrm{pg} / \mathrm{mL}$.

\section{Tissue IL-6}

The value of IL-6 was evaluated using a commercially available rat IL-6 ELISA kit (Invitrogen; CA, USA). Absorbance was evaluated at a wavelength of $450 \mathrm{~nm}$ using the ELISA plate reader. The intra-assay coefficients of variation were $3.5 \%$ and inter-assay coefficients of variation $6.3 \%$. The LOD for the IL- 6 assay was $<5 \mathrm{pg} / \mathrm{mL}$.

\section{Immunohistochemistry}

The liver tissues were fixed in $10 \%$ neutral formaldehyde for 24 hours before being washed under running water for eight hours. Then they were rinsed out with an ethanol-xylene series and embedded into liquid paraffin using an automated tissue follow-up system (Citadel 2000, Thermo Fisher Scientific; Shandon, England). The liver tissues were cut into 3-4 $\mu \mathrm{m}$ thick sections using a rotary microtome (RM2255, Leica; Wetzlar, Germany) in preparation for immunohistochemical staining. The sections were kept in xylene for 20 min before applying an alcohol series (50-100\%), followed by a $10 \mathrm{~min}$ incubation in an $\mathrm{H}_{2} \mathrm{O}_{2}$ solution. They were then washed in PBS, heated for $4-5 \mathrm{~min}$ in a citrate buffer solution by 800 -Watt power, before incubating in a secondary blocker substance for $20 \mathrm{~min}$. Before being stained with an anti-CA-II antibody (code: ab124687, Abcam Plc.; Cambridge, UK) or an anti-CPS-1 antibody (code: ab45956, Abcam Plc.; Cambridge, UK), each slide was put in different dilutions of primary antibody (anti-CPS1 $1 \mu \mathrm{g} / \mathrm{mL}$; anti-CAII $1 / 250-/ 500$ ) for $75 \mathrm{~min}$. Diaminobenzidine solution was employed as a chromogen and Mayer's hematoxylin was utilized as a counterstain for 3-5 min. PBS was operated as a negative control. After being covered with proper covering materials (Entellan mounting medium, code: 107960, Merc; Darmstadt, Germany), all preparations were photographed using a digital camera (DP72, Olympus; Tokyo, Japan) attached to a light microscope (BX51, Olympus; Tokyo, Japan). The histopathological examination as performed in the previous studies, after immunohistochemical staining, the preparations were divided into four categories according to the proportion of immunopositive reaction regions of the tissue: mild $(+)$, moderate $(++)$, severe $(+++)$, and very severe $(++++)(15,16)$.
The tissue blocks were cut into 4-5- $\mu \mathrm{m}$ tsections before being stained by hematoxylin and eosin (H\&E) for histopathological examination. The sections have been stained by H\&E and they were blindly evaluated by two histologists and a pathologist. A previously used hepatotoxicity-scoring system for liver injury by Cure et al. (16) was used as a model. The evaluation included cell degeneration, cell vacuolization, edema, lymphocytic infiltration and cell loss. Scoring from 0 to 4 was considered as mild $(+)$, moderate $(++)$, severe $(+++)$ and very severe $(++++)(16)$.

\section{Statistical analysis}

In this study, all data analyses were performed using the statistical software SPSS for Windows (version 13.0; SPSS Inc.; Chicago, IL, USA). The differences among the groups were appraised by Kruskal-Wallis variance analysis test. When the p-value was statistically significant after Bonferroni correction, pairwise comparisons were carried out using MannWhitney $\mathrm{U}$ test. The biochemical and histopathological results were presented as means \pm SD. Statistically, significant differences were obtained at a $p$ value of less than 0.017 .

\section{RESULTS}

\section{Biochemical analysis}

The level of AST in the Cis group (67.0 $18.0 \mathrm{IU} / \mathrm{L})$ was much higher than in the control group $(41.0 \pm 11.4 \mathrm{IU} / \mathrm{L}, \mathrm{p}=0.001)$. The level of AST in the Cis group was higher than in the CIN group $(60.3 \pm 12.1 \mathrm{IU} / \mathrm{L})$, but it was not statistically significant. The level of ALT in the Cis group (70.3 $\pm 15.8 \mathrm{IU} / \mathrm{L})$ was much higher than in the control group $(38.7 \pm 10.9 \mathrm{IU} / \mathrm{L}, \mathrm{p}<0.001)$ (Table 1). The level of ALT in the Cis group was higher than in the CIN group (57.2 $\pm 14.3 \mathrm{IU} / \mathrm{L})$, but it was not statistically significant (Table 1). The tissue level of TNF- $\alpha$ in the Cis group ( $345.5 \pm 40.0 \mathrm{pg} / \mathrm{mg}$ protein) was considerably higher than in the CIN group (278.7 $\pm 62.1 \mathrm{pg} / \mathrm{mg}$ protein, $\mathrm{p}=0.013)$ and the control group $(239.0 \pm 64.2 \mathrm{pg} / \mathrm{mg}$ protein, $\mathrm{p}=0.003)$ (Table 1). Tissue levels of IL- 6 in the Cis group $(487.7 \pm 43.7 \mathrm{pg} / \mathrm{mg}$ protein) were much higher than in the control group $(400.3 \pm 36.1 \mathrm{pg} / \mathrm{mg}$ protein, $\mathrm{p}=0.001$ ). The level of IL- 6 in the Cis group was higher than in the CIN group (441.9 $\pm 43.7 \mathrm{pg} / \mathrm{mg}$ protein), but the difference was not statistically significant (Table 1).

\section{Histological analysis}

According to the histopathological examination via light microscopy, no cellular deformities were found in the control group liver, stained by $\mathrm{H} \& \mathrm{E}$ and immunohistochemical staining methods (Figure 1a). The morphologic structures of the cells and tissues had normal histology. Epithelial cells, drain- 
TABLE 1. Effect of Infliximab on serum and tissue biochemical parameters in Cis-induced hepatotoxicity, analyzed by the Kruskal-Wallis test and Mann-Whitney U Test

\begin{tabular}{|c|c|c|c|c|}
\hline & $\begin{array}{c}\text { Cis }(\mathrm{n}=10) \\
(\mathrm{mean} \pm \mathrm{SD})\end{array}$ & $\begin{array}{l}\mathrm{CIN}(\mathrm{n}=10) \\
(\mathrm{mean} \pm \mathrm{SD})\end{array}$ & $\begin{array}{c}\text { Control }(\mathrm{n}=10) \\
(\text { mean } \pm \mathrm{SD})\end{array}$ & $\mathrm{p}$ \\
\hline AST (IU/L) & $67.0 \pm 8.0^{*}$ & $60.3 \pm 12.1^{*}$ & $41.0 \pm 11.4$ & 0.001 \\
\hline $\operatorname{ALT}(\mathrm{IU} / \mathrm{L})$ & $70.3 \pm 15.8^{*}$ & $57.2 \pm 14.3^{*}$ & $38.7 \pm 10.9$ & 0.001 \\
\hline TNF- $\alpha$ (pg/mg protein) & $345.5 \pm 40.0 *$ & $278.7 \pm 62.1$ & $239.0 \pm 64.2$ & 0.004 \\
\hline IL-6 (pg/mg protein) & $487.7 \pm 43.7 *$ & $441.9 \pm 43.7$ & $400.3 \pm 36.1$ & 0.015 \\
\hline
\end{tabular}

Cis: cisplatin; CIN: cisplatin and Infliximab; TNF- $\alpha$ : tumor necrosis factor-alpha; IL-6: interleukin-6; AST:aspartate transaminase; ALT:alanine transaminase.

$* \mathrm{p}<0.017$ compared with control (Mann-Whitney U Test with Bonferroni correction).

"p $<0.017$ compared with CIN (Mann-Whitney U Test with Bonferroni correction).

TABLE 2. Effect of Infliximab on histopathology of liver tissue in Cis-induced hepatotoxicity (scale of 0 to 4), analyzed by Kruskal-Wallis test and Mann-Whitney U Test

\begin{tabular}{lcccc}
\hline & $\begin{array}{c}\text { Cis }(\mathrm{n}=10) \\
(\operatorname{mean} \pm \mathrm{SD})\end{array}$ & $\begin{array}{c}\mathrm{CIN}(\mathrm{n}=10) \\
(\operatorname{mean} \pm \mathrm{SD})\end{array}$ & $\begin{array}{c}\text { Control }(\mathrm{n}=10) \\
(\operatorname{mean} \pm \mathrm{SD})\end{array}$ & 0.001 \\
\hline Cell degeneration & $3.9 \pm 0.3^{*}, \pi$ & $2.8 \pm 0.4^{*}$ & $0.8 \pm 0.4$ & 0.001 \\
Cell vacuolization & $3.2 \pm 0.4^{*}, \pi$ & $1.8 \pm 0.4^{*}$ & $0.2 \pm 0.4$ & 0.001 \\
Edema & $3.1 \pm 0.3^{*}, \pi$ & $2.2 \pm 0.6^{*}$ & $0.7 \pm 0.5$ & 0.001 \\
Lymphocyte infiltration & $2.9 \pm 0.3^{*}, \pi$ & $1.9 \pm 0.3^{*}$ & $0.0 \pm 0.0$ & 0.001 \\
Cell loss & $3.8 \pm 0.6^{*}, \pi$ & $2.7 \pm 0.5^{*}$ & $0.7 \pm 0.5$ & 0.001 \\
CA-II & $2.2 \pm 0.4^{*}, \pi$ & $1.1 \pm 0.3$ & $3.2 \pm 0.4$ & 0.001 \\
CPS-1 & $1.8 \pm 0.4^{*}, \pi$ & $2.8 \pm 0.4$ & &
\end{tabular}

Cis: cisplatin; CIN: cisplatin + infliximab; CA-II: carbonic anhydrase-II; CPS-1: carbamoyl phosphate synthetase -1

${ }^{*} \mathrm{p}<0.017$ compared with control (Mann-Whitney U Test with Bonferroni correction)

" $\mathrm{p}<0.017$ compared with CIN (Mann-Whitney U Test with Bonferroni correction)

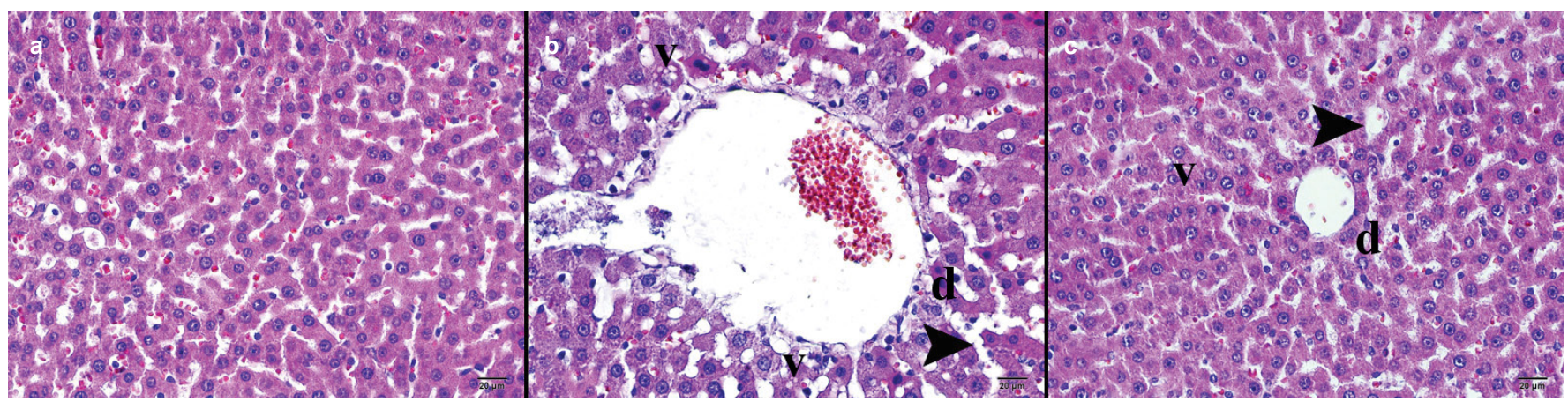

FIG. 1. a-c. Histopathological examination of liver tissue by light microscopy with hematoxylin \& eosin staining. The morphologic structures of the cells and tissues had normal histology (a). Evaluation of the Cis group by light microscopy showed dense basophilic contents and swelling of the hepatocytes (b). Examination of the CIN group by light microscopy showed a decrease in the growth of hepatocytes with mild basophilic contents (c).

d: degenerating cell v: vacuolization; arrowhead: sinusoidal dilatation, X400.

ing channels, endothelial cells and vessels of the portal region had a normal histological morphology, in addition to rounded nuclei and eosinophilic cytoplasm of normal big polygonal hepatocytes. Sinusoids among hepatic cords were normal and the Kupffer cells were located on their walls facing the lumen. The perilobular connective tissue had a normal appearance and the vessels were normal (Table 2).
Evaluation of the Cis group by light microscopy showed dense basophilic contents and swelling of the hepatocytes (Figure 1b). The hepatocytes around the central veins had dense, irregularly shaped clusters of degenerative cells with nuclei surrounded by empty vacuoles, a sign of necrotic hepatocytes. (Table 2). There was an increase in apoptotic cells associated with high-density vacuolar degeneration of hepatocytes adjacent to 


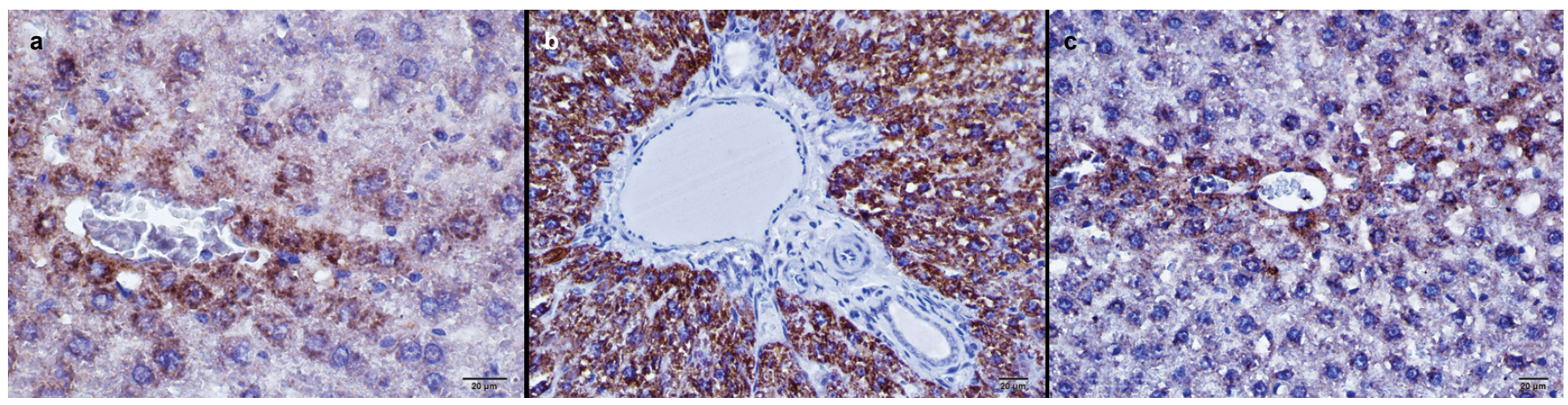

FIG. 2. a-c. Anti-CA II antibody immunohistochemical staining of liver tissues. Control group (a), Cis applied to the group (b), Cis and Ib applied to the group, immunoperoxidase-stained Anti-CA II antibody, X400 (c). Carbonic anhydrase II activity in the Cis group was much higher than in the control group and the CIN group.

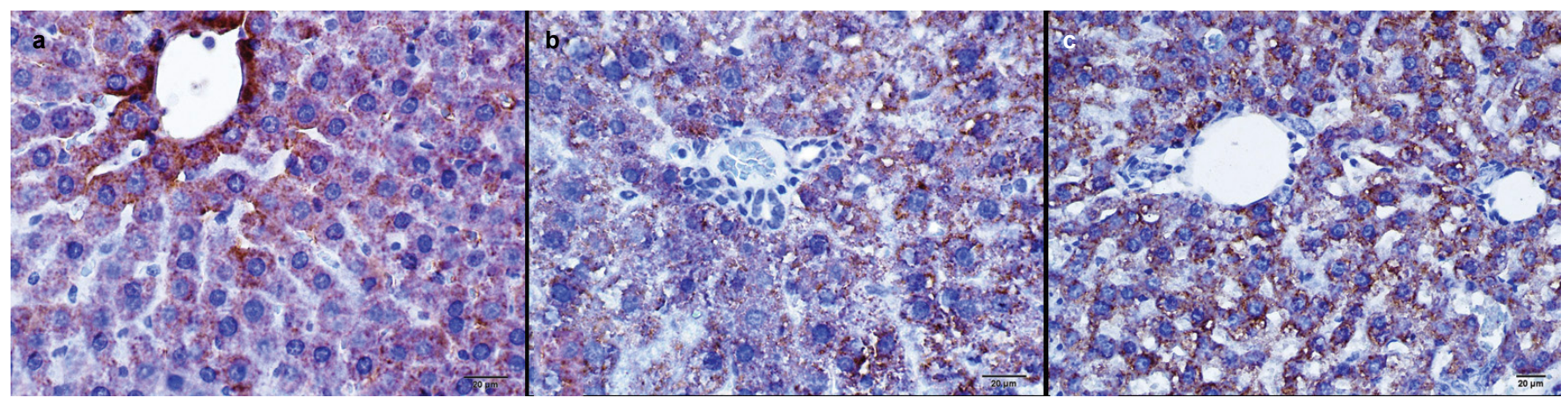

FIG. 3. a-c. Immunohistochemical staining of liver tissues with immunoperoxidase method, anti CPS-I antibody. Control group (a), Cis applied to the group (b), Cis and Ib applied to the group, immunoperoxidase stained anti-CPS-I antibody, X400 (c). CPS-1 activity in the Cis group was significantly lower than in the control group and the CIN group.

the central veins. A small amount of perivascular round cell infiltration was considered in the portal area due to the increase in the connective tissue. Additionally, there were extensive expansions in the sinusoidal spaces. Some very slightly eosinophilic hepatocytes were found to have normal morphology. Edema and hepatization were observed in the large vessels (Table 2).

Examination of the CIN group by light microscopy showed a decrease in the growth of hepatocytes with mild basophilic contents (Figure 1c). There was a decrease in hepatocyte necrosis in regions surrounding the central veins. Even though there were not many empty vacuoles, they were observed, accompanied by cell degeneration. In the regions of low vacuolar degeneration, lightly stained apoptotic cells were observed besides easily distinguishable hepatocytes. Perivascular round cell infiltration was observed in the connective tissues of the portal area. There was a decrease in the sinusoidal dilatations among the hepatic cords (Table 2).

Carbonic anhydrase II activity in the Cis group was much higher than in the control group $(\mathrm{p}<0.001)$ and the CIN group $(p<0.001)$ (Figure 2, Table 2). CPS-1 activity in the Cis group was significantly lower than in the control group $(\mathrm{p}<0.001)$ and the CIN group $(\mathrm{p}<0.001)$ (Figure 3, Table 2).

\section{DISCUSSION}

In the current study, we examined the possible preventive effects of Ib on Cis-induced hepatotoxicity. Histopathological and biochemical examinations of the liver showed that the administration of Ib reduced Cis-induced liver damage. In our study, histopathological evaluation of the Cis-treated group revealed cell degeneration, cellular loss, vacuolization and extensive lymphocytic infiltration; however, the CIN group had less histopathological damage than in the Cis group.

Cis-induced liver toxicity is associated with ROS. High doses of Cis may lead to excessive formation of ROS, contributing to oxidative stress and its complications such as inflammation, which is characterized by excessive production of the cytokines TNF- $\alpha$ and IL-6, and the activation of a cascade through inflammatory signaling pathways $(17,18)$. Elevated levels of free radicals and pro-inflammatory cytokines with a concomitant decline in exogenous and endogenous antioxidants may cause injury to cellular organelles in the liver. Increased ROS and pro-inflammatory cytokines have been demonstrated to induce hepatocyte apoptosis (19).

Aspartate transaminase and ALT are widely used in tests as markers of hepatocellular damage. Aminotransferases 
may increase excessively and abruptly during toxic hepatitis. However, alone these tests are insufficient to indicate the severity of liver damage and the prognosis; they are less effective than histopathological examination $(20,21)$. In this study, AST and ALT levels in the Cis group were higher than in the CIN group. However, these differences were not statistically significant. The presence of high AST and ALT levels in the Cis and CIN groups indicates hepatocellular damage related to Cis overdose. However, histopathological damage in the CIN group was lower than in the Cis group.

Tumor necrosis factor alpha, an important pro-inflammatory cytokine, is released from activated macrophages. TNF- $\alpha$ and its superfamily members are known to have both beneficial and harmful effects. The increased production of ROS can accelerate the expression of nuclear factor kappa $\mathrm{B}$ and proinflammatory cytokines such as TNF- $\alpha$ and IL-6, which could increase the cytotoxic effects of Cis in liver tissues (22). A previous study has shown that UTL-5g-a novel small-molecule TNF- $\alpha$ inhibitor protects the liver from Cis-induced hepatotoxicity, as indicated by lowering the elevated levels of AST, ALT, and TNF- $\alpha$ (23). Another study has shown Ib administration to dramatically lower serum ALT, AST and TNF- $\alpha$ levels (4). It has been reported that Ib decreases ROS, TNF- $\alpha$, and apoptosis in Cis-induced intestinal damage in rats (24).

Infliximab reaches the effective blood level after three days; therefore, in this study we applied Cis after three days of $\mathrm{Ib}$ administration (5). In the current study, TNF- $\alpha$ and IL-6 levels in the Cis group were higher than in the control group. TNF- $\alpha$, IL- 6 , AST and ALT levels in the CIN group were lower than in the Cis group. However, the differences were not statistically significant. Ib may prevent hepatotoxicity by inhibiting TNF- $\alpha$ and decreasing pro-inflammatory cytokines produced secondary to Cis-induced ROS. Besides, histological findings of CIN group have been shown Ib to be effective in preventing cellular damage.

Tumor necrosis factor alpha was known as a cytokine that could kill cancer cells; however, sometimes it can cause the reproduction, invasion, and metastasis of cancer cells (25). Therefore, elevated TNF- $\alpha$ levels may have deleterious outcomes. High TNF- $\alpha$ levels are related to anti-angiogenesis, whereas low levels are associated with pro-angiogenic effects (26). In the literature, there have been case reports of patients treated with $\mathrm{Ib}$ who developed cancer because of decreased TNF- $\alpha$ levels (27). In the current study, the CIN group had lower TNF- $\alpha$ levels than the Cis group. However, it was not lower than the control group. The moderate elevation of TNF- $\alpha$ by the combination of Cis and Ib might prevent cancer development.

Carbonic anhydrase II is highly synthesized in numerous tissues, including the liver. It catalyzes the reversible reaction that occurs between carbon dioxide and bicarbonate (14).
Overexpression of CA-II enhances $\mathrm{Cl}^{-} / \mathrm{HCO}_{3}^{-}$exchange activity, which can lead to elevated levels of intracellular bicarbonate (28). Increased CA-II causes the conversion of surplus bicarbonate to carbonate radicals $(29,30)$. Recent studies have suggested carbonate radicals to be the major mediator of various types of oxidative damage (31). Conversely, the inhibition of CA-II activity causes metabolic acidosis. Cure et al. have reported Ib to decrease the nephrotoxic effects of Cis overdose in renal tissues (11). In this study, while the activity of CAII in the Cis group was obviously higher than in the control group, the activity of CA-II in the CIN group was similar to in the control group. The level of CA-II in kidney tissue is higher than in liver tissue, and the nephrotoxic effect of Cis is more obvious than the hepatotoxic effect. Therefore, Cis may have different effects on CA-II enzyme levels in each individual tissue. A previous study reported that $\mathrm{Ib}$ prevented kidney damage by inhibiting metabolic acidosis, caused by decreased CA-II levels (11). We have found out that Ib ameliorates liver injury by preventing oxidative stress which arises from increased CA-II levels. Perhaps, Ib may regulate CA-II enzyme levels in some tissues such as liver and kidney tissues.

Carbamoyl phosphate synthetase-1, a 1,463-amino acid polypeptide, catalyzes the three-step considered to be the key step reaction of the urea cycle. In the reaction, carbamoyl phosphate is produced from ammonia, bicarbonate, and adenosine triphosphate (32). If the CPS-1 activity is decreased, this may raise serum bicarbonate levels $(15,33)$. The bicarbonate-dependent peroxidase activity of the scavenger enzyme superoxide dismutase converts hydrogen peroxide to carbonate radicals, which oxidize the enzyme (34). Elevated CA-II enzyme activity accompanied by low CPS-1 enzyme activity may lead to increased levels of bicarbonate and peroxynitrite radicals, thus inducing tissue damage.

As carcinoma cells have an advanced replication rate than normal cells, they require more bicarbonate to participate in these metabolic pathways. Bicarbonate is a substrate for carbonic anhydrase enzymes and so its isoforms play a prominent role in the growth of tumor cells (35). Bicarbonate exists in plenty of tissues with superior CA-II enzyme level, such as gastric cancer, hepatocellular carcinoma and gall duct cancers, colorectal cancer, kidney cancers, melanoma, astrocytoma, pancreatitis cells in mouse and myocardial cell hypertrophy (36). In our study, the level of CA-II was elevated in rats given cisplatin, whereas the level of CPS-1 was low. The high level of CA-II and low level of CPS-1 might increase bicarbonate and peroxynitrite levels, leading to liver tissue damage. CA-II and CPS- 1 activities were similar in both the CIN group and the control group. The concomitant intake of $\mathrm{Ib}$ and Cis may show a synergistic effect. Taking these two drugs together may decrease bicarbonate levels via these enzymes, leading 
to a decrease in tumor growth. However, the mechanism of action of both drugs on these enzymes is unclear.

\section{Limitations of the study}

In this study, it would have been interesting to investigate the preventative effect of $\mathrm{Ib}$ against hepatotoxicity in an experimental cancer model. However, as the toxic effect of Cis overdose on CA-II and CPS-1 in liver tissues and the preventive effect of $\mathrm{Ib}$ against this toxicity remain to be elucidated, our study lays the groundwork for future studies using cancer models.

In conclusion, Cis overdose may lead to liver damage by increasing cytokine production and ROS formation. Additionally, it may increase oxidative stress-induced tissue damage by increasing CA-II enzyme levels and decreasing CPS-1 enzyme levels. Ib is a potent TNF- $\alpha$ inhibitor. We suggest that it decreases Cis overdose-induced hepatic damage by blocking TNF- $\alpha$. Ib may also protect against liver damage by regulating the activity of CPS-1 and CA-II.

Ethics Committee Approval: Ethics committee approval was received for this study from the ethic committee of Rize University Local Ethics Committee for Animal Experiments (App. No: 2012/23).

\section{Informed Consent: N/A.}

Peer-review: Externally peer-reviewed.

Author contributions: Concept - E.C., Y.K., A.K.T.; Design L.T., A.Y., İ.Ş.; Supervision - A.Y., A.K.T., Y.K.; Resource - M.C.C, A.K, S.Y.; Materials - M.C.C, L.T., İ.Ş; Data Collection and/or Processing - E.C., Y.K., A.Y.; Analysis and/or Interpretation - Y.K., M.C.C, A.K.; Literature Search - S.Y., A.K, L.T.; Writing - M.C.C., E.C, S.Y.; Critical Reviews - Y.K., A.K.T., İ.Ş.

Conflict of Interest: No conflict of interest was declared by the authors.

Financial Disclosure: The authors declared that the study was funded by Scientific Research Project Unit (Bilimsel Araştırmalar Proje Birimi, BAP) of Recep Tayyip Erdoğan University (Project No: 2012.106.01.5).

\section{REFERENCES}

1. Bentli R, Parlakpinar H, Polat A, Samdanci E, Sarihan ME, Sagir M. Molsidomine prevents cisplatin-induced hepatotoxicity. Arch Med Res 2013;44:521-28. [CrossRef]

2. Waseem M, Parvez S. Mitochondrial dysfunction mediated cisplatin induced toxicity: modulatory role of curcumin. Food Chem Toxicol 2013;53:334-42. [CrossRef]

3. Karadeniz A, Simsek N, Karakus E, Yildirim S, Kara A, Can I, et al. Royal jelly modulates oxidative stress and apoptosis in liver and kidneys of rats treated with cisplatin. Oxid Med Cell Longev 2011;981793. [CrossRef]

4. Ferah I, Halici Z, Bayir Y, Demirci E, Unal B, Cadirci E. The role of infliximab on paracetamol-induced hepatotoxicity in rats. Immunopharmacol Immunotoxicol 2013;35:373-81. [CrossRef]

5. Mahmoud MF, El Shazly SM, Barakat W. Inhibition of TNF- $\alpha$ protects against hepatic ischemia-reperfusion injury in rats via NF-кB dependent pathway. Naunyn Schmiedebergs Arch Pharmacol 2012;385:465-71. [CrossRef]

6. Amanzada A, Moriconi F, Mansuroglu T, Cameron S, Ramadori G, Malik IA. Induction of chemokines and cytokines before neutrophils and macrophage recruitment in different regions of rat liver after TAA administration. Lab Invest 2014;94:235-47. [CrossRef]

7. Cure E, Kirbas A, Tumkaya L, Cure MC, Kalkan Y, Yilmaz A, et al. Protective effect of infliximab on methotrexate-induced liver injury in rats: Unexpected drug interaction. J Cancer Res Ther 2015;11:164-9. [CrossRef]

8. Sehitoglu I, Tumkaya L, Bedir R, Ozer E, Cure MC, Kalkan Y, et al. Protective Effect of Infliximab Against Carbon Tetrachloride-Induced Hepatotoxicity. J Environ Pathol Toxicol Oncol 2015;34:175-82. [CrossRef]

9. Shah GN, Rubbelke TS, Hendin J, Nguyen H, Waheed A, Shoemaker JD, et al. Targeted mutagenesis of mitochondrial carbonic anhydrases VA and VB implicates both enzymes in ammonia detoxification and glucose metabolism. Proc Natl Acad Sci USA 2013;110:7423-8. [CrossRef]

10. Lapenna D, Ciofani G, Cuccurullo C, Neri M, Giamberardino MA, Cuccurullo F. Bicarbonate-dependent, carbonate radical anion-driven tocopherol-mediated human LDL peroxidation: an in vitro and in vivo study. Free Radic Res 2012;46:1387-92. [CrossRef]

11. Cure E, Kirbas A, Tumkaya L, Cure MC, Sahin OZ, Kalkan Y, et al. Effect of infliximab against cisplatin-induced nephrotoxicity. Saudi Med J 2014;35:953-8.

12. Diez-Fernandez C, Martinez AI, Pekkala S, Barcelona B, PerezArellano I, Guadalajara AM, et al. Molecular characterization of carbamoyl-phosphate synthetase (CPS1) deficiency using human recombinant CPS1 as a key tool. Hum Mutat 2013;34:114959. [CrossRef]

13. Santi A, Caselli A, Paoli P, Corti D, Camici G, Pieraccini G, et al. The effects of CA IX catalysis products within tumor microenvironment. Cell Commun Signal 2013;11:81. [CrossRef]

14. Cayır K, Karadeniz A, Simşek N, Yıldırım S, Karakuş E, Kara A, et al. Pomegranate seed extract attenuates chemotherapyinduced acute nephrotoxicity and hepatotoxicity in rats. $J$ Med Food 2011;14:1254-62. [CrossRef]

15. Cure E, Cumhur Cure M, Tumkaya L, Kalkan Y, Aydin I, Kirbas A, et al. Adalimumab ameliorates abdominal aorta cross clamping which induced liver injury in rats. Biomed Res Int 2014;2014:907915. [CrossRef]

16. Cure E, Cure MC, Tumkaya L, Kalkan Y, Aydin I, Kirbas A, et al. Topiramate ameliorates abdominal aorta cross-clamping induced liver injury in rats. Saudi J Gastroenterol 2014;20:297303. [CrossRef] 
17. Dkhil MA, Al-Quraishy S, Aref AM, Othman MS, El-Deib KM, Abdel Moneim AE. The potential role of Azadirachta indica treatment on cisplatin-induced hepatotoxicity and oxidative stress in female rats. Oxid Med Cell Longev 2013;2013:741817. [CrossRef]

18. Ingawale DK, Mandlik SK, Naik SR. Models of hepatotoxicity and the underlying cellular, biochemical and immunological mechanism(s): a critical discussion. Environ Toxicol Pharmacol 2014;37:118-33. [CrossRef]

19. Hoek JB, Pastorino JG. Ethanol, oxidative stress, and cytokineinduced liver cell injury. Alcohol 2002;27:63-8. [CrossRef]

20. James O, Lesna M, Roberts SH, Pulman L, Douglas AP, Smith $\mathrm{PA}$, et al. Liver damage after paracetamol overdose. Comparison of liver-function tests, fasting serum bile acids, and liver histology. Lancet 1975;2:579-81. [CrossRef]

21. Limdi J, Hyde G. Evaluation of abnormal liver function tests. Postgrad Med J 2003;79:307-12. [CrossRef]

22. Shaw J, Chen B, Lee AR, Media J, Valeriote FA. The smallmolecule TNF- $\alpha$ inhibitor, UTL-5g, delays deaths and increases survival rates for mice treated with high doses of cisplatin. Cancer Chemother Pharmacol 2013;72:703-07. [CrossRef]

23. Shaw J, Chen B, Huang WH, Lee AR, Media J, Valeriote FA. The small-molecule TNF-alpha modulator, UTL-5g, reduces side effects induced by cisplatin and enhances the therapeutic effect of cisplatin in vivo. J Exp Ther Oncol 2011;9:129-37.

24. Aydin I, Kalkan Y, Ozer E, Yucel AF, Pergel A, Cure E, et al. The protective effect of infliximab on cisplatin-induced intestinal tissue toxicity. Eur Rev Med Pharmacol Sci 2014;18:2076-83.

25. Omatsu H, Kuwahara A, Yamamori M, Fujita M, Okuno T, Miki I, et al. TNF- $\alpha-857 \mathrm{C}>\mathrm{T}$ genotype is predictive of clinical response after treatment with definitive 5-fluorouracil/cisplatin-based chemoradiotherapy in Japanese patients with esophageal squamous cell carcinoma. Int J Med Sci 2013;10:1755-60. [CrossRef]

26. Hudesman D, Lichtiger S, Sands B. Risk of extraintestinal solid cancer with anti-TNF therapy in adults with inflammatory bowel disease: review of the literature. Inflamm Bowel Dis 2013;19:644-9. [CrossRef]
27. Yu M, Zhou X, Niu L, Lin G, Huang J, Zhou W, et al. Targeting transmembrane TNF- $\alpha$ suppresses breast cancer growth. Cancer Res 2013;73:4061-74. [CrossRef]

28. Sowah D, Casey JR. An intramolecular transport metabolon: fusion of carbonic anhydrase II to the $\mathrm{COOH}$ terminus of the $\mathrm{Cl}(-) / \mathrm{HCO}(3)(-)$ exchanger, AE1. Am J Physiol Cell Physiol 2011;301:C336-46. [CrossRef]

29. Gebicka L, Didik J, Gebicki JL. Catalytic scavenging of peroxynitrite by lactoperoxidase in the absence and presence of bicarbonate. Free Radic Res 2010;44:217-23. [CrossRef]

30. Cure MC, Cure E, Tumkaya L, Kalkan Y, Aydin I, Kirbas A, et al. Topiramate has protective effect on renal injury. Bratisl Lek Listy 2015;116:259-63. [CrossRef]

31. Carballal S, Bartesaghi S, Radi R. Kinetic and mechanistic considerations to assess the biological fate of peroxynitrite. Biochim Biophys Acta 2014;1840: 768-80. [CrossRef]

32. Lopes-Marques M, Igrejas G, Amorim A, Azevedo L. Human carbamoyl phosphate synthetase I (CPSI): insights on the structural role of the unknown function domains. Biochem Biophys Res Commun 2012;421:409-12. [CrossRef]

33. Martinez AI, Perez-Arellano I, Pekkala S, Barcelona B, Cervera J. Genetic, structural and biochemical basis of carbamoyl phosphate synthetase 1 deficiency. Mol Genet Metab 2010;101:311-23. [CrossRef]

34. Queiroz RF, Paviani V, Coelho FR, Marques EF, Di Mascio P, Augusto $\mathrm{O}$. The carbonylation and covalent dimerization of human superoxide dismutase 1 caused by its bicarbonate-dependent peroxidase activity is inhibited by the radical scavenger tempol. Biochem J 2013;455:37-46. [CrossRef]

35. Csaderova L, Debreova M, Radvak P, Stano M, Vrestiakova M, Kopacek J, et al. The effect of carbonic anhydrase IX on focal contacts during cell spreading and migration. Front Physiol 2013;4:271. [CrossRef]

36. Liu LC, Xu WT, Wu X, Zhao P, Lv YL, Chen L. Overexpression of carbonic anhydrase II and Ki-67 proteins in prognosis of gastrointestinal stromal tumors. World $J$ Gastroenterol 2013;19:2473-80. [CrossRef] 